\title{
TONANTZIN CORONADA EN EL TLALOCAN
}

\section{Por Manuel González Galván}

Tonantzintla es un monumento a la ternura. Ternura que arranca desde la raíz indígena de su nombre, Tonantzin - nuestra madrecitay tlan locativo, Tonantzintla es pues "el lugar de nuestra madrecita".

Desde la época prehispánica se veneraba ahí a la diosa madre. Evangelizada la tierra, después de la Conquista, el culto a la Virgen María parece, más que suplantación, la continuidad lógico-cristiana de una prefiguración.

El santuario mariano manifiesta, artísticamente, la estrecha liga entre la población y el culto a la "madrecita", creándose un monumento único en el panorama del arte popular nacional.

La confianza en los favores de la Virgen y el tierno deseo de que Ella se encuentre contenta, ha llevado a varias generaciones a poner sus cuidados en la decoración y enriquecimiento del templo, vertiendo en él todo lo que su imaginación desea y no puede poseer en lo particular. Es la versión popular, llena de libertad expresiva, en que el indigena replica al arte culto de la vecina capilla poblana del Rosario, pero con formas de mayor libertad y un colorido tan rico que recuerda el de los juguetes de feria.

Como producto de religiosidad popular, Tonantzintla no es la obra de un solo mecenas o autor, ni siquiera de una época determinada, sino la aportación continua de la devoción de los fieles que parte del siglo xvir para apenas irse concluyendo en nuestros días.

Comenzó por ser una pequeña construcción de una sola nave con cúpula y torre, a la que posteriormente, en el siglo xvirr, se añadieron los cruceros, ampliándose finalmente la nave hacia el frente y desapareciendo la primitiva fachada al hacerse la actual. La bóveda que cubre el coro apenas fue cerrada en junio de 1897 (lámina 1).

La deslumbrante decoración interior se realizó, en su mayor parte, durante el siglo xviII, cuando la comunidad indigena se sintió con suficientes arrestos para emular la maravillosa decoración criolla de la Capilla del Rosario en la cercana ciudad de Puebla, obra que, al ser concluida en 1690, había pasmado a la región. No bastó ni satisfizo al gusto del pueblo la adquisición de retablos salomónicos y churriguerescos para su iglesia; era necesario cubrir todos los planos como en el ejemplo de yesería poblana, y si los recursos económicos no permitían. 
traer un alarife o maestro yesero acreditado, pues Tonantzintla era, y es aún, una casi insignificante vicaría, el pueblo, confiado en sí mismo y en el gusto de anónimos diseñadores salidos de él, emprendió la magna tarea de cubrir con ornamentación el interior del templo, sembrando con amor muros, arcos y bóvedas, que florecieron en un fastuoso, abigarrado e inmarcesible jardín de increíble y atrevida policromía.

El interior de Tonantzintla produce una sugestión mágica, la imaginación queda estupefacta y no puede sustraerse, a menos que se cierren los ojos, ante el cosmos plástico, tan agitado y brillante como, a la vez, estático. Subyuga el total recubrimiento (láminas 2 y 3 ).

La pequeña, pero hechizante iglesia, es ponderada como una de las obras maestras del barroco popular mexicano; su decoración exuberante atrae visitas constantes de los gustadores de arte, en tanto que los investigadores pretenden mayormente desentrañar, cada vez más, las causas y el proceso de su creación; entre ellos especialmente la han amado y dado a conocer: el Dr. Atl, Manuel Toussaint, Diego Angulo, Francisco de la Maza y Pedro Rojas.

El estudio formal e histórico alcanza el grado de casi exhaustivo en el libro monográfico de Pedro Rojas, ${ }^{1}$ donde sintetiza hallazgos y opiniones anteriores, da su personal opinión y apunta sugerencias; pero la intención alegórica de aquel mundo de figurillas resulta confusa por su misma abundancia, complicando la interpretación.

Francisco de la Maza intuye en todo esto una reminiscencia del concepto indígena del Paraíso cuando nos dice: ${ }^{2}$

Los indios de Chulula debieron sentirse auténticamente maravillados ante la Octava Maravilla como, cada quien a su manera, sucede ahora y sucederá mientras perdura la sensibilidad del espíritu humano. Pero la Capilla del Rosario no era, precisamente, para ellos. ¿Qué les importaba el raudal de estricta y sabia Teologia que derrama al observador la Capilla del Rosario? ¿Qué sentido tenía la presencia en ella de La Gracia, concepto de alta teología que aun a gentes cultas se les escapa y olvida?

Hacer suya aquella muestra de arte y devoción fue la tarea que se impusieron. "Traducirla" a su lenguaje; "adaptarla" a su sensibilidad. $Y$ de alli nació, a principios del siglo xviI (no sabemos exactamente cuando) la capilla de Santa María Tonantzintla, precisamente con su nombre azteca que quiere decir "nuestra madrecita".

1 Pedro Rojas, Tonantzintla. Colección de Arte, núm. 2, UNAM. México, 1956 (recientemente reeditado).

2 Francisco de la Maza, "Tonantzintla, Paraiso", en la revista Sembradores de Amistad. Monterrey, N. L., junio de 1965, año xvir, vol. xx, núm. 164. p. 3, 
Ahora bien, nosotros nos preguntamos, moviéndonos en el mundo de los supuestos, si se da por hecho que la existencia del decorado de Tonantzintla se debe a un impulso de emulación de la poblana Capilla del Rosario, ¿̨por qué tan sólo en lo formal se iba a desear una obra equiparable en riqueza, que no copia literal? ¿Y por qué no se habría de buscar también un alma, un simbolismo, o para decirlo con palabras de su tiempo, unos "jeroglíficos" que le dieran razón, sin que tampoco fueran los mismos del esplendoroso ejemplo y sólo coincidieran en exaltar a la misma gran Señora?

En otro hermoso y profundo párrafo insiste De la Maza en considerar a Tonantzintla una resurrección de la idea paradisiaca indígena, y amplía la idea explicándola históricamente: ${ }^{3}$

Esta visión policromada, sensual, hedonista, del paraíso, se oscureció con la Conquista. El cristianismo habló a los oídos de los indios de un paraíso igual, pero perdido, pasado ya. Otro era el que vendría, pero sin materializarse nada en él, sin trasladar nada de este mundo. Ese paraíso futura era sólo la beatífica contemplación de Dios, que había que ganarse con el hábito de las nuevas virtudes traídas de Occidente. El indígena tuvo que olvidar las delicias de su Tlalocan.

Pero vino después un tiempo propicio en el que pudieron surgir los escondidos veneros de la antigua imaginación poética y mágica que la Conquista obligó a dormir en el fondo de la subconciencia. Fue en el siglo del Barroco, en el xvin, cuando pudieron aflorar de nuevo los sentimientos y los deseos reprimidos. En esa época, también, el gobierno colonial y el alto clero consideraron al indígena plenamente convertido e integrado al catolicismo y hubo una libertad que no se había tolerado en el siglo xvi. E1 indio y el criollo, cada uno por su lado y en su forma, se entregaron de lleno al Barroco, que les permitió externarse, extrovertirse, sobre todo en la plástica, la más alejada de la censura oficial.

$Y$ es entonces cuando surge Tonantzintla bajo el manto de la ortodoxia, pero sin ser la obra teológica que es, por ejemplo, la $\mathrm{Ca}$ pilla del Rosario de Puebla. No es tampoco que sea una iglesia heterodoxa, es sincrética. Es el Tlalocan del siglo xvmr. Es el Tlalocan con vestiduras católicas y aun con religiosidad católica, pero teñiida de trascendencias y realidades prehispánicas. Es, nuevamente, el paraíso terrenal de flores y frutos. Es el anticipo, en este mundo, del futuro paraíso, colorido y sensual, traslado de este mundo en sus mejores condiciones.

3 De la Maza, op. cit, p. 5. 
Pedro Rojas, por su lado, también se pregunta si hay una justificación simbólica para tanto fausto decorativo $y$, aunque no afirma nada categóricamente y hasta duda lo pueda haber, sugiere posibles orientaciones de la misma, coincidentes en mucho con lo que nosotros pensamos que representa. Así, nos dice: 4

Resta volver los ojos a lo alto y esperar del estucado tapiz que lo cubre, un lenguaje que articule la anhelante veneración a María y la belleza sin la que todo amor y profundidad se disipan.

¿Pura decoración? ¿No lo es en el tambor de la cúpula y sí en las otras partes del templo? Debe notarse que el gran infante del crucero desciende hacia la clave del arco, en donde se modeló una gran corona dirigida hacia el presbiterio, y que de esta manera el Espíritu y el niño casi seguramente quieren decir algo y podrian aludir a que por la gracia y por la encarnación, María es reina entre los ángeles y los hombres.

La distribución de los motivos principales que exornan las bóvedas, también debe tener una intención simbólica. Se forma una cruz con el eje longitudinal que partiendo del presbiterio pasa por el centro de la cúpula donde está el Espíritu Santo, desciende por donde se encuentra el infante desnudo, sigue por la corona de la clave del arco del crucero y se prolonga hasta la clave del siguiente donde hay un anagrama de María. Esta línea tendría una dedicación a la Virgen y al niño. El eje transversal tiene en sus dos extremos al Padre y al Hijo y en el centro al Espiritu Santo de la cúpula. Esta otra línea estaría dedicada a la Trinidad.

La dedicación trinitaria del crucero es inobjetable y, además, Rojas está casi a punto de referirse a lo que creemos representan justamente la cúpula y cruceros, "en donde se modeló una gran corona dirigida hacia el presbiterio", como él mismo lo dice, sin que el célebre niño descendente, que tanto ha intrigado a los investigadores, no pase de ser una más, aunque de mayor tamaño, de las numerosas figuras que, en último caso, sólo se asocia a las otras dos que bajo el arco sostienen la "gran corona" para así aludir, una vez más, a la Trinidad. Y, más concretamente, pensamos que este grupo no constituye otra cosa sino la simple réplica que el ignorado maestro de Tonantzintla hace de otra Trinidad infantil, que existe en la Capilla del Rosario poblano y, valga la zontradicción, tan descollante como oculta, pues en lo alto y al fondo se representa, nada menos que como remate o culminación del marco que guarda el gran lienzo de la Glorificación de Maria, con que se

\footnotetext{
4 Pedro Rojas, op cit, pp. 33 y 35 .
} 
recubre el ábside de la capilla. Ahí, en ese distinguido cuanto último rincón, dos niños desnudos sostienen la corona, en tanto otro "descendente", de cabeza hacia abajo, simula sostener, o se aferra con las manos, a la orilla del marco, en forma muy similar a como lo hace la figura más agrandada de Tonantzintla, con el arco que separa la nave de la cúpula, con una fórmula y composición plástica tan próxima a la del Rosario, que hace indudable suponer el grupo de Tonantzintla surgido directamente de la observación de la capilla poblana.

Considerado todo lo anterior y por el interés que ello mismo provoca, intentamos aquí, en adelante, una interpretación alegórica de Tonantzintla que se ajuste tanto a la tradición mariana del catolicismo cuanto lógicamente pueda corresponder, en el aspecto iconográfico, al tan, al parecer, errabundo remolino decorativo.

Creemos que la iglesia de Tonantzintla, además de todas las reminiscencias prehispánicas que indudablemente posee, no por ello deja de tener, dada su finalidad, una marcada estructura simbólica, definitivamente católica y ortodoxa, dentro de la dogmática.

Como en la generalidad de las iglesias barrocas las abundantes imágenes no están colocadas con arbitrariedad, sino informando o conformando alguna alegoria cimentada en argumentos teológicos. Adelantando la idea que pretendemos mostrar -si no demostrar- más claramente después, creemos que el símbolo eje de la decoración es, como lo indica la distribución de las figuras, una glorificación de María que tiene como tema iconográfico esencial el de la Coronación de Maria en los cielos, o Tonantzin Coronada en el Tlalocan, si se prefiere, dado el intenso indigenismo de la obra que ha hecho notar De la Maza, de quien volvemos à recordar otro párrafo: ${ }^{5}$

Todo es color. Todo es flores de grandes pétalos y de frutos abiertos. ¿No es esto la viva realización de los trozos de Sahagún y Torquemada aplicados por don Alfonso Caso al Tlalocan de Teotihuacan? En el siglo xvin pudieron los nahoas de Puebla reconstruir su paraíso como un "traslado de la naturaleza" según frase de un viejo cronista. Cierto que no hay agua, pero cno la supone la floración radiante de los elementos de la tierra? Cierto que ya no es Tláloc y los Tlaloques los invocados; son Santa María y los santos, pero que en el fondo

5 Francisco de la Maza, "El Tlalocan pagano de Teotihuacan y el Tlalocan cristiano de Tonantzintla", en el libro Homenaje al Dr. Alfonso Caso. México, 1951, pp. 277-282. En este artículo, por primera vez De la Maza dio a conocer su interpretación de Tonantzintla como Tlalocan redivivo, idea que posteriormente conformó y desarrollo en otras publicaciones. 
no son sino el disfraz, el nahual, de las viejas divinidades prehispánicas, no muertas del todo en el melancólico indio de los valles de México que, cuando pudo, recreó su paraíso.

Así pues, si estas flores y frutos entre los que se divierten las almas niñas indigenas, son la versión dieciochesca del paraíso prehispánico, si este edén conserva aquella flora y fauna, su color y hasta su olor de paganismo, sin embargo, ya es un Tlalocan sin Tláloc; los visjos dioses han desaparecido y en su lugar se pasea una señora, a la que sólo con idioma filial nos podemos dirigir: Tonantzin, "nuestra madrecita". Ella ha recultivado el viejo jardín y aunque resta mucho de lo antiguo, el nuevo riego (llamado católicamente Gracia) lo ha bañado con nueva savia transformándolo en un distinto reino del espíritu.

En Tonantzintla se representa a María glorificada y coronada por la relación que guarda con Cristo; sin Él, Ella no se explica ni justifica; pero en María Cristo encarnó y tomó naturaleza humana; por tanto, es colmada de privilegios.

La nave o cuerpo de la iglesia, como en la Capilla del Rosario de Puebla, alude a la vida terrena en que María se unió a Cristo en la obra redentora; por ello es acertada la presencia, en primer lugar, de Cristo y algunos santos, aunque éstos no siguen un orden claro y lógico con respecto a la simetría y composición formal del templo (lámina 4).

Entrando, a la izquierda, en el coro y sobre la puerta que corresponde sobre el bautisterio, está Cristo representado como el Nazareno de la pasión, cargado con el patíbulo o sección transversal de la cruz, curiosa coincidencia con recientes investigaciones cristológicas que prueban cómo efectivamente así debió ser.

La colocación de esta imagen en el lugar correspondiente al bautisterio es correcta, pues con el Bautismo el hombre se hace cristiano, es el "hombre nuevo" que nace a la vida de la gracia y se convierte en seguidor de Cristo al aceptar y tomar la cruz como el Redentor lo pide.

A la derecha del Nazareno, un San Cristóbal nos recuerda "el que lleva a Cristo" y pone su esfuerzo al servicio de los valores espirituales. San Cristóbal es también símbolo de la evangelización porque lleva a Cristo a través de los obstáculos físicos, ríos o mares, por lo cual se representa enorme, pues gigante debe ser quien realice tal hazaña. $\mathrm{Al}$ otro lado del Cristo y haciendo juego con San Cristóbal, un San Francisco representa a las órdenes monásticas, las más aptas para la labor misional, dada su organización. Este San Francisco, colocado en el costado izquierdo de la cruz que forma el espacio interno de la capilla, con la calavera 
del ascetismo en sus manos y un pie sobre la gran bola azul del mundo, recuerda vivamente las representaciones pictóricas, sobre todo las tan popularizadas que provienen de Murillo, en que el santo con su pie derecho apoyado en el mundo y colocado igualmente al lado izquierdo de la cruz, recibe a Cristo amorosamente y se entrega a Él para ampliar la obra redentora.

Frente a estas figuras, está San Nicolás de Tolentino, solo, y es difícil de asociar como propósito alegórico, aunque no queda por demás, como recuerdo del sacrificio personal que debe acompañar a la vida religiosa. Hay que citar a San Diego de Alcalá y a San Antonio de Padua, los que se encuentran colocados en el centro del peralte que hacen los arcos bajos del crucero, al parecer figuras también sobradas, como las imágenes del principio, pero al igual que ellas son un símbolo complementario, ya que nos recuerdan la virtud de ser humildes en la grandeza espiritual, virtud que en la Virgen constituye uno de sus más preciados atributos; además, San Antonio y San Diego son santos franciscanos y no se debe olvidar que esta zona fue mucho tiempo administrada religiosamente por los franciscanos.

Ahora bien, si estas primeras imágenes no siguen un orden sistemático en relación con la composición decorativa, y su significado no tiene un total acuerdo central, y hasta resulta muy dudoso saber si hubo intención alegórica en su presencia y colocación, en cambio, como veremos, las alusiones marianas, tema principal de la obra, si siguen una rigurosa secuencia que abarca todo el conjunto, integrándolo en torno a un principal tema que resulta ser la Coronación de la Virgen en los cielos, y el orden iconográfico es tan lógico que hace suponer un posible programa o, al menos, un asesor religioso-esporádico, ya que la decoración se efectuó en distintas etapas, las que, pese a ello, resultan congruentes: ${ }^{6}$

Las aplicaciones de estuco son de diversas épocas. La más antigua y al mismo tiempo la mejor concebida y realizada es la que ocupa la bóveda del ábside, todo el crucero y los arcos y pilastres que separan al crucero del resto de la bóveda principal. Son posteriores la de la bóveda y la de los medios puntos en que se apoyan sus tres tramos comprendidos entre el crucero y la fachada, así como los de las alturas de los brazos cortos del crucero. La decoración de todas estas partes debió hacerse progresivamente, tocándole lo último a la parte del coro cuya bóveda se terminaba de cerrar para 1897, según hemos

6 Pedro Rojas, op. cit., p. 26. 
hecho notar. El sotocoro que tiene un estucado de características diferentes, debió ser también de lo último en decorarse.

El hilo simbólico arranca de la bóveda del sotocoro donde, en la clave y al centro, aparece una pequeña escultura estofada que suponemos alude a la Asunción o traslado Angélico de María en cuerpo y alma gloriosos, imagen que sustituye u ocupa el lugar de esta figura de la misma Virgen María, pues entre toda la decoración de yeserías aplicadas por muros y bóvedas, ésta es la única representación que parece no corresponder al sitio en que se encuentra ya que, al parecer, fue aquí colocada tan sólo por el hecho de hacer palpable la presencia de María, pues hasta técnicamente su factura es ajena; no es de estuco, sino una breve escul. tura exenta tallada en madera y estofada. Lleva en su brazo izquierdo un diminuto Niño Jesús, apenas perceptible a la distancia, además de que toda la figura resulta demasiado pequeña para el área del medallón que la enmarca. Creemos, por todo esto, que no siendo original de este sitio, la esculturita se sobrepuso a la bóveda del sotocoro, simplemente por ser una representación mariana, lo que no invalida la sugerencia asuncional de la decoración que la rodea, reforzada con la presencia de nubes en que se apoya y el cielo estrellado que le sirve de fondo, así como por los numerosos niños-ángeles que le hacen rueda; tenantes del medallón unos, músicos otros $y$, por sobre todo, la presencia de la paloma del Espíritu Santo que cerca de ella, en la clave del arco toral de la bóveda, es indudable alegoría de la Gracia y el poder divinos por los que Maria es glorificada y llevada a los cielos; así la que había sido concebida sin pecado y refulgía con el don de la Maternidad Divina, no podía quedar sujeta a la corrupción corporal del sepulcro puesto que fue el "vaso de elección" para la Encarnación de Cristo.

Es de notarse el acierto de colocación alegórico, ya que si la Virgen fue llevada de la tierra a los cielos, qué mejor alusión a ello que la bóveda del sotocoro; la más cercana a la tierra entre los elementos arquitectónicos que cubren la estructura (figura 1).

En seguida, avanzando hacia el altar, el símbolo continúa en la bóveda. mayor, pues en la clave del arco central de la nave dos ángeles llevan el anagrama de María, lo que equivale a transportarla para que, finalmente, la confirmada en gracia sea confirmada en gloria al ser entronizada y coronada por la Trinidad misma, que esto, creemos, se representa. 


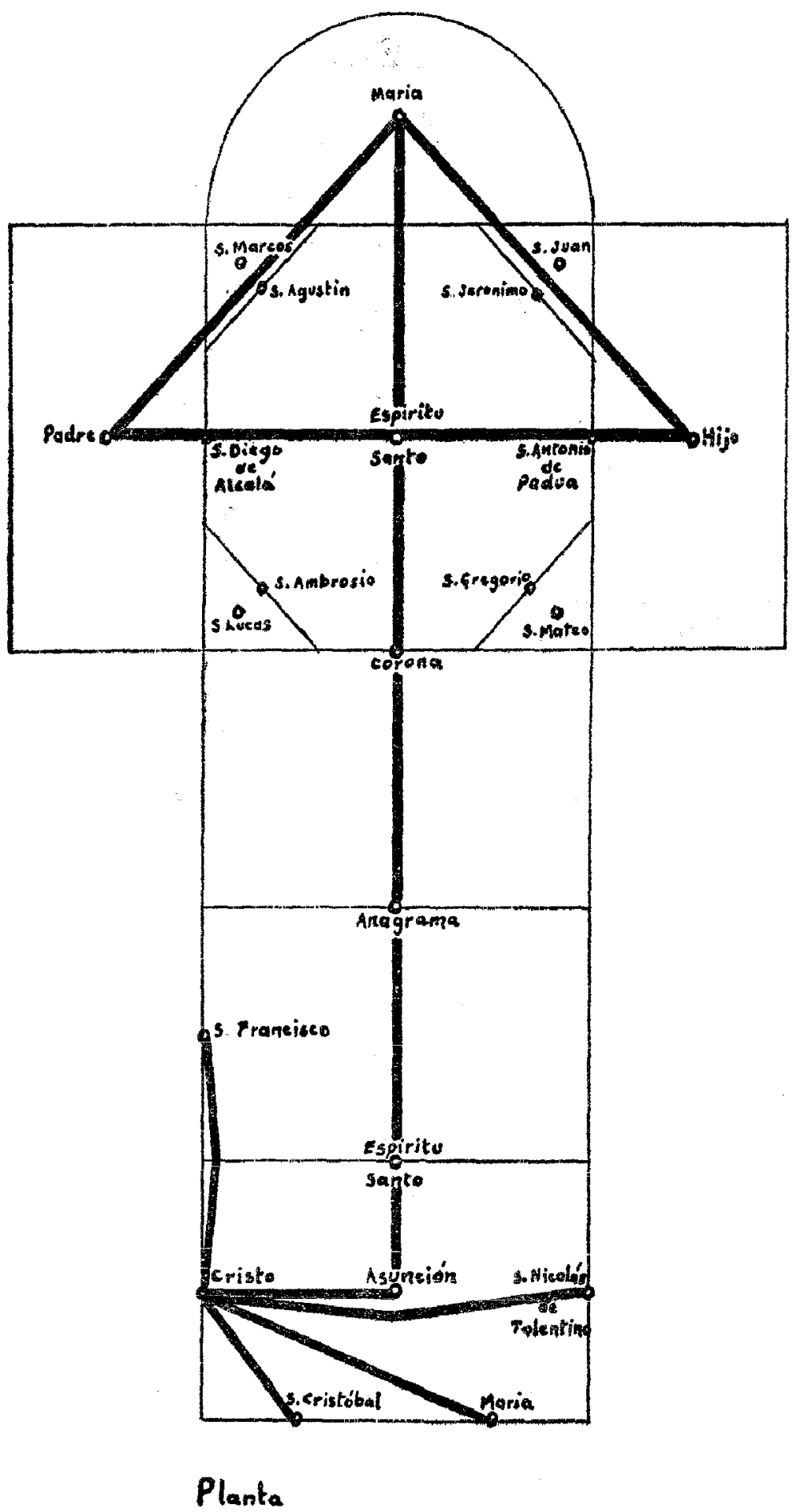

Figura 1. Distribución de las imágenes en la decoración estucada de Tonantzintla. 


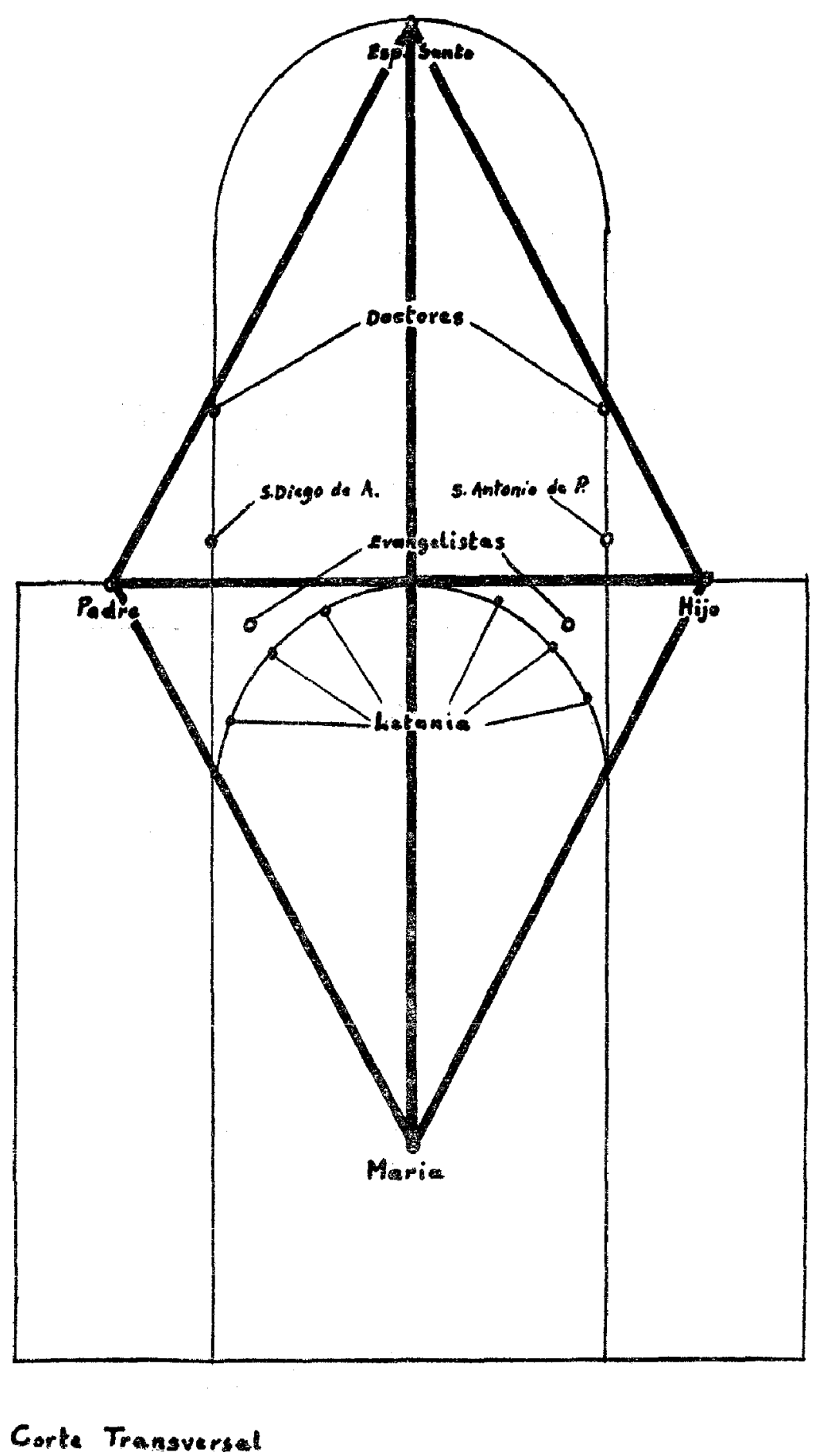

Figura 2. Relación de imágenes entre cruceros, cúpula y ábside de Tonantzintla. 


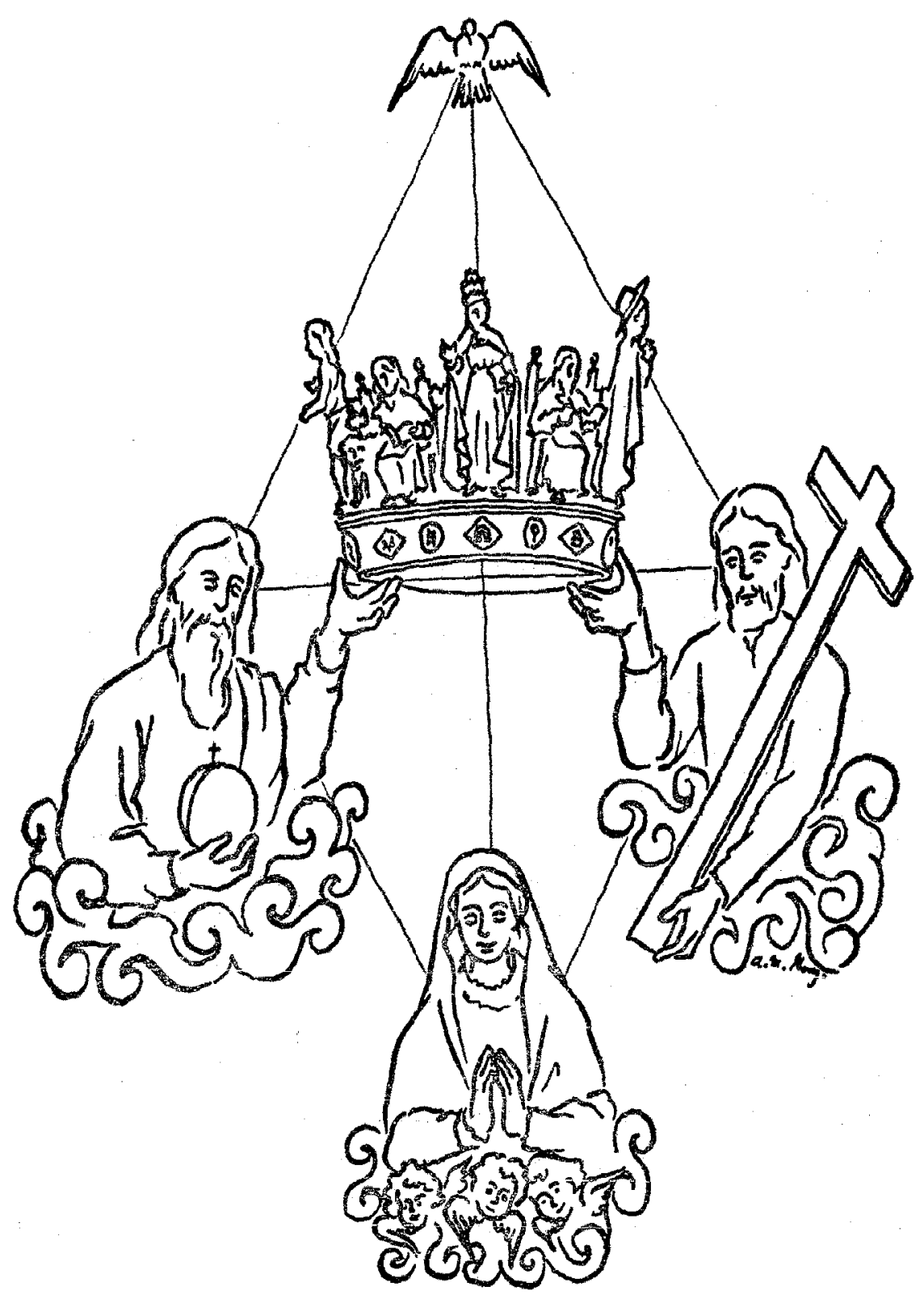

Figura 3. Alegoría de la Coronación de la Virgen representada por medio de imágenes $\mathrm{y}$ elementos arquitectónicos en Tonantzintla. 
en el crucero y ábside como tema predominante, al que aluden las imágenes y decoración en su mayor significado y abundancia: ${ }^{7}$

La última escena del ciclo de la Virgen María es aquella en que su Divino Hijo la recibe y la corona como reina del Cielo. La Coronación de la Virgen había sido presagiada por un episodio de la vida de Salomón, Betsabé, su madre, fue a pedirle un favor. "Pasó, pues, Betsabé a ver al rey Salomón...., y levantóse el rey a recibirla, y la saludó con profunda reverencia; sentóse después en su trono y pusieron un trono... para la madre del rey, la cual se sentó a su derecha." (I Reyes 2, 19.)

Lo anterior, tal parece, fue perfectamente conocido en el mundo colonial, puesto que un pintor "culto" del siglo xvin, como lo fue Juan Correa y nada menos que en la sacristía de la Catedral de México, representó en un gran lienzo esta recepción celestial de María, la que después de su Asunción ya tiene preparado un trono en la Gloria, su Hijo sale a recibirla mientras el Padre la espera con la corona en sus manos, ante la radiante presencia del Espíritu Santo (láminas 5 y 6 ).

De esta manera se funde y relaciona en Tonatzintla, con clara y correcta iconografía, la secuencia de la Asunción (la nave), con la Coronación (el crucero y ábside), fórmula nada ajena al arte colonial, sino por el contrario muy frecuente en la obra de los pintores.

En la clave del arco que divide la nave del crucero, dos ángeles sostienen una corona (lámina 7), puesto que la conjunción crucero, cúpula y ábside, configuran la Coronación siguiendo una distribución similar a la de las innumerables representaciones pictóricas del tema (láminas 8 y 9). El Padre a la izquierda y el Hijo a la derecha del observador (láminas 10 y 11), se encuentran en el centro de la bóveda del crucero, sosteniendo así, sobre Maria, la esplendorosa cúpula transformada en su corona, cúpula que remata la paloma del Espíritu Santo aludiendo de nuevo a la asistencia divina y a la relación de la Virgen con la Trinidad (lámina 12). Completando el símbolo, el intradós de los arcos torales muestra, como joyas de la diadema mariana, figuras de la Letanía Lauretana: la Fuente de la Divina Gracia, la Puertá del Cielo, la Palma de Cadez, la Oliva que da el bálsamo, el Espejo de Justicia, el Pozo de Sabiduría, la Casa de Oro, el Huerto Cerrado y Jardín Florido...

Si se corta idealmente el crucero, un rombo es la figura geométrica

1 George Ferguson, Signos y simbolos en el arte cristiano. Emecé Editores, Buenos Aires, 1956, p 101. 
DOI: http://dx.doi.org/10.22201/iie.18703062e.1978.48.1093

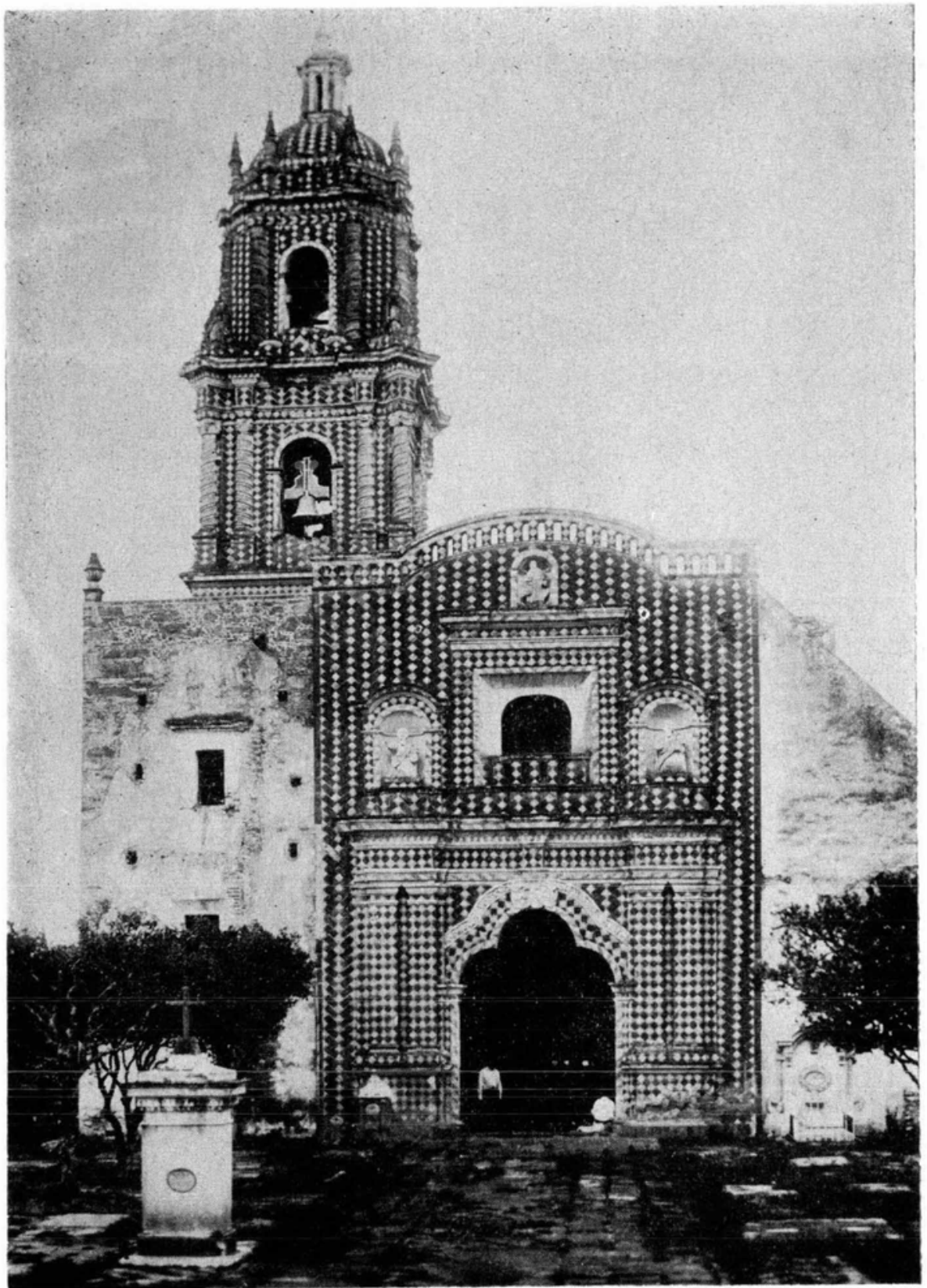

Lámina 1. Santa María Tonantzintla, fachada. Al ampliarse la nave hacia el frente, a fines del sigle xix, la torre antigua queda retraída. 
DOI: http://dx.doi.org/10.22201/iie.18703062e.1978.48.1093

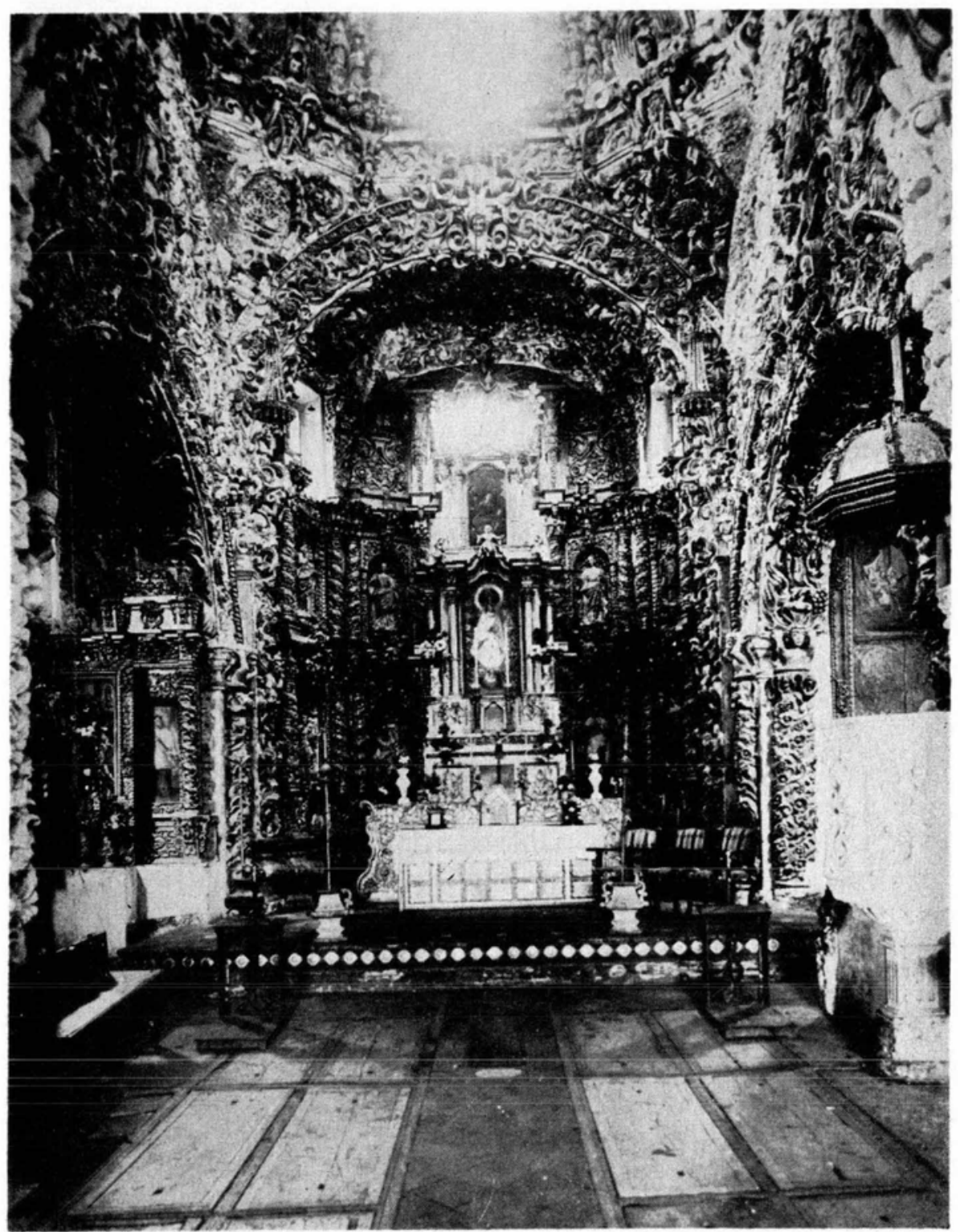

Lámina 2. Interior de Tonantzintla. Fotografía de principios de este siglo en la que pueden apreciarse algunos elementos modificados o desaparecidos; es digno de notarse el ciprés neoclásico, hoy transformado, y los desaparecidos sepulcros en el piso. 


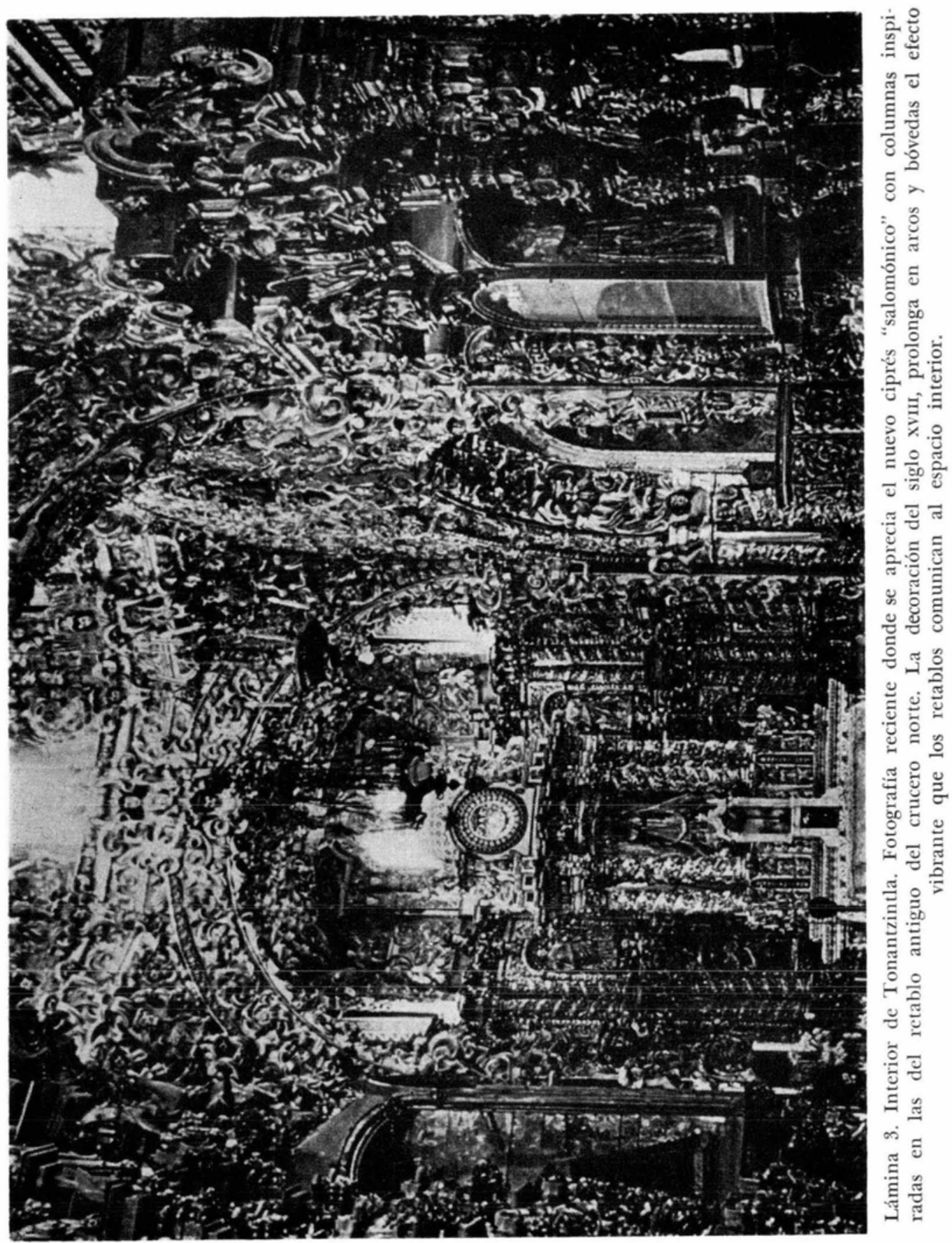




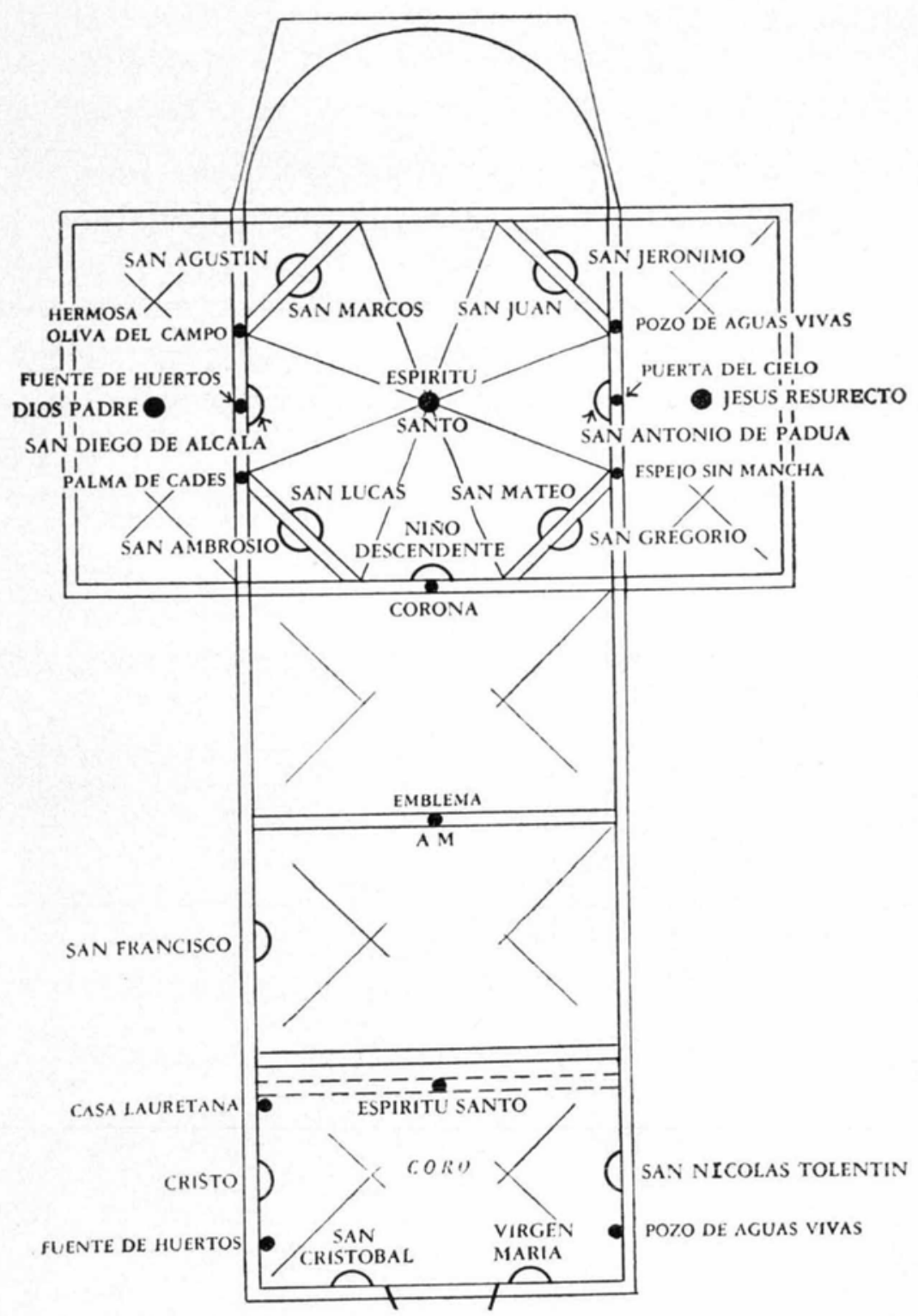

Localización de las figuras de estuco que exornan las aliuras del templo

Lámina 4. Localización de imágenes en la decoración estucada de muros, arcos y bóvedas. 


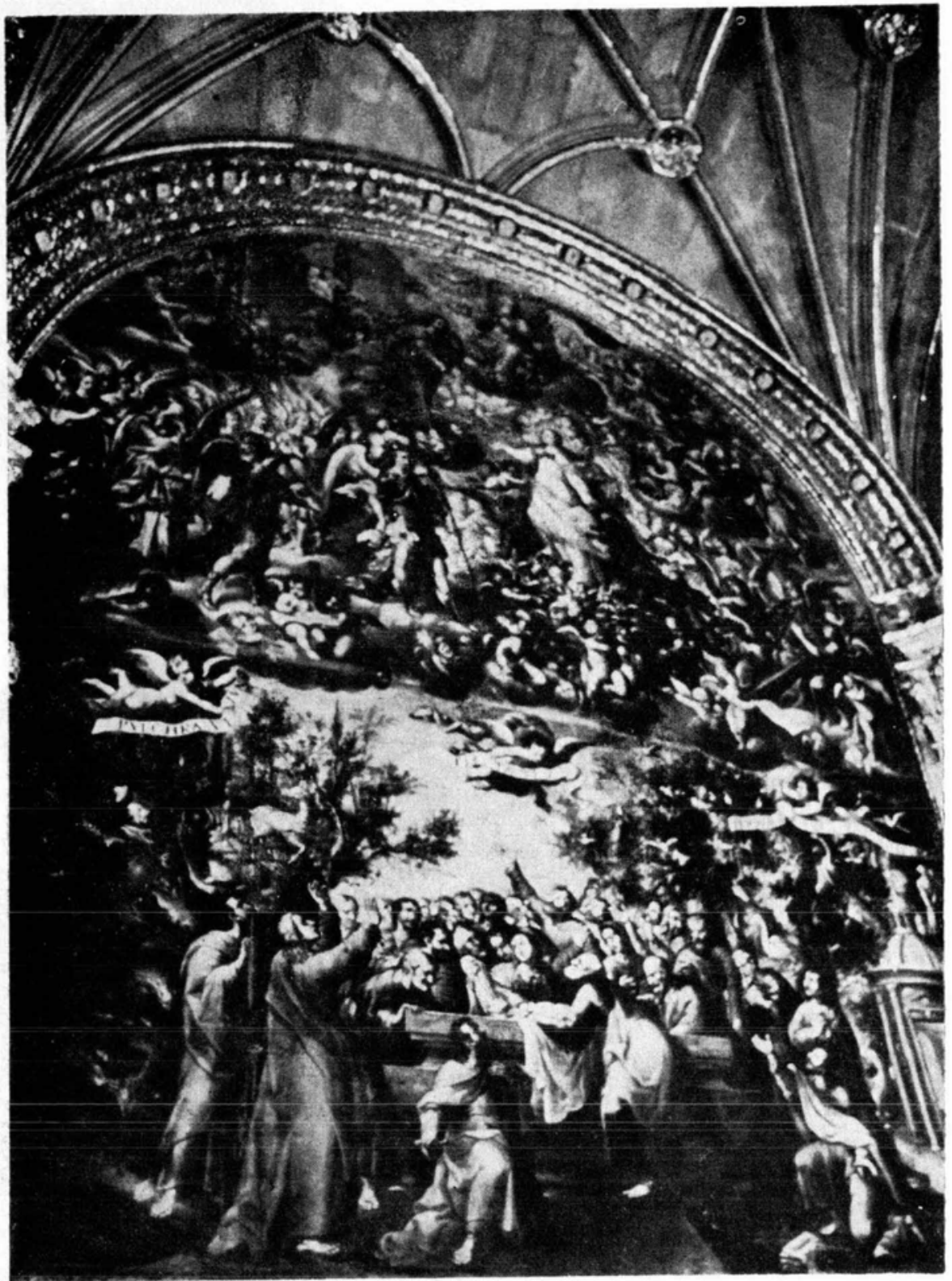

Lámina 5. Juan Correa. Sacristía de la Catedral de México. Los apóstoles ante el sepulcro vacío. Parte inferior del gran lienzo que representa la Asunción de la Virgen. Segunda mitad del siglo xvII. 


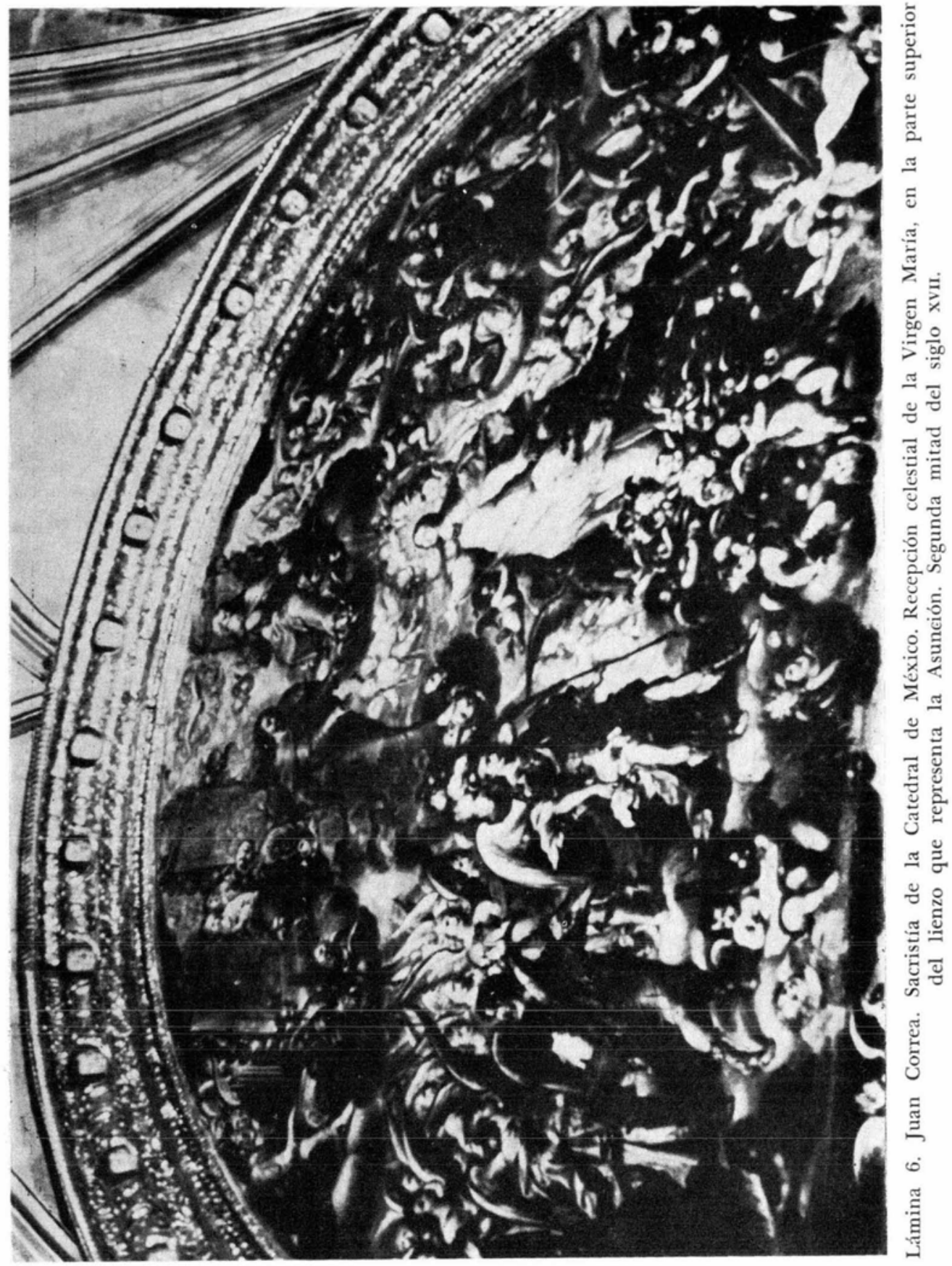




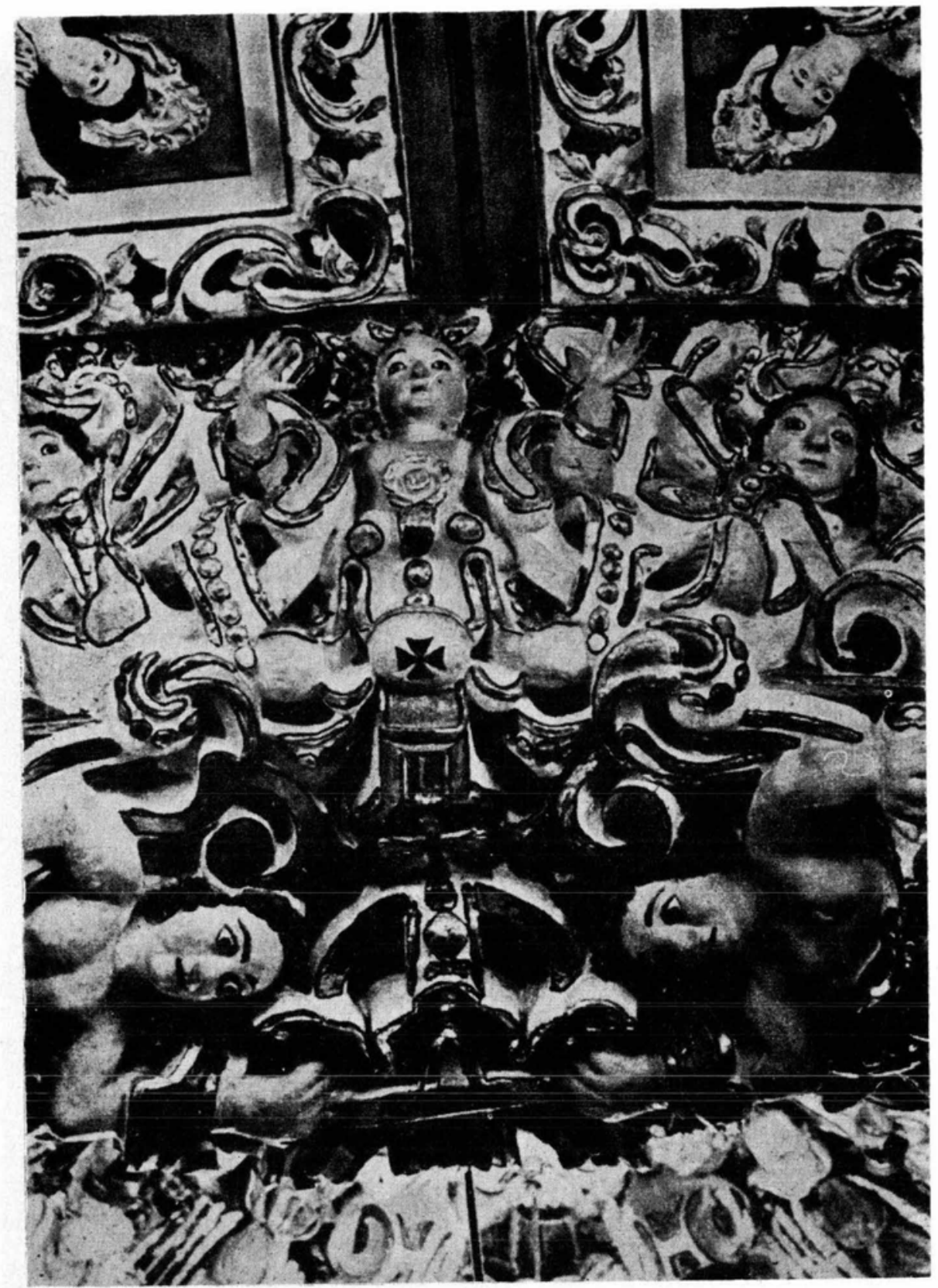

Lámina 7. La corona en el intradós del arco toral que separa la cúpula de la nave. 
DOI: http://dx.doi.org/10.22201/iie.18703062e.1978.48.1093

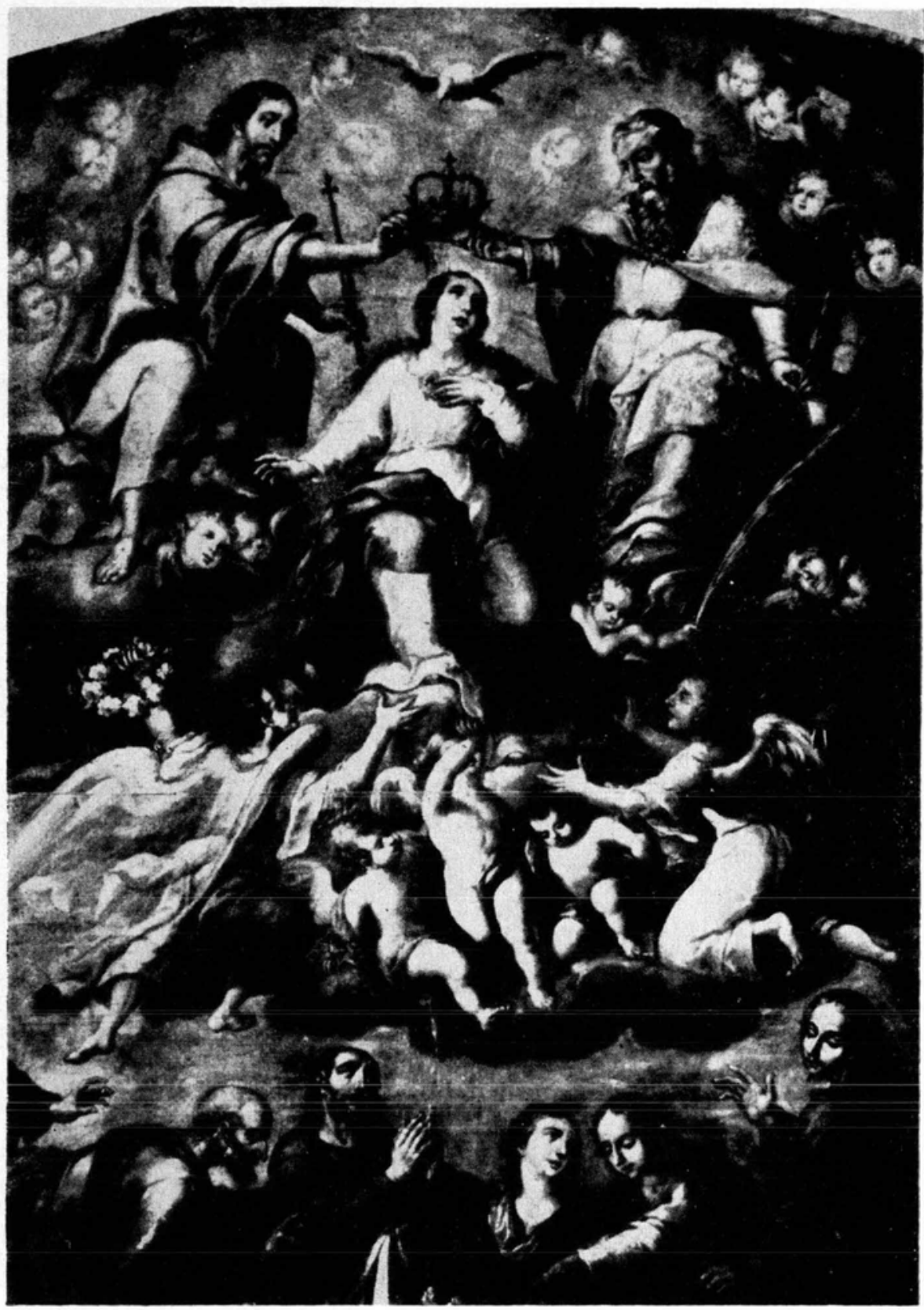

Lámina 8. Juan Correa. Coronación de la Virgen. Siglo xvII. En la parte inferior los apóstoles ante el sepulcro vacio aluden a La Asunción de María. 
DOI: http://dx.doi.org/10.22201/iie.18703062e.1978.48.1093

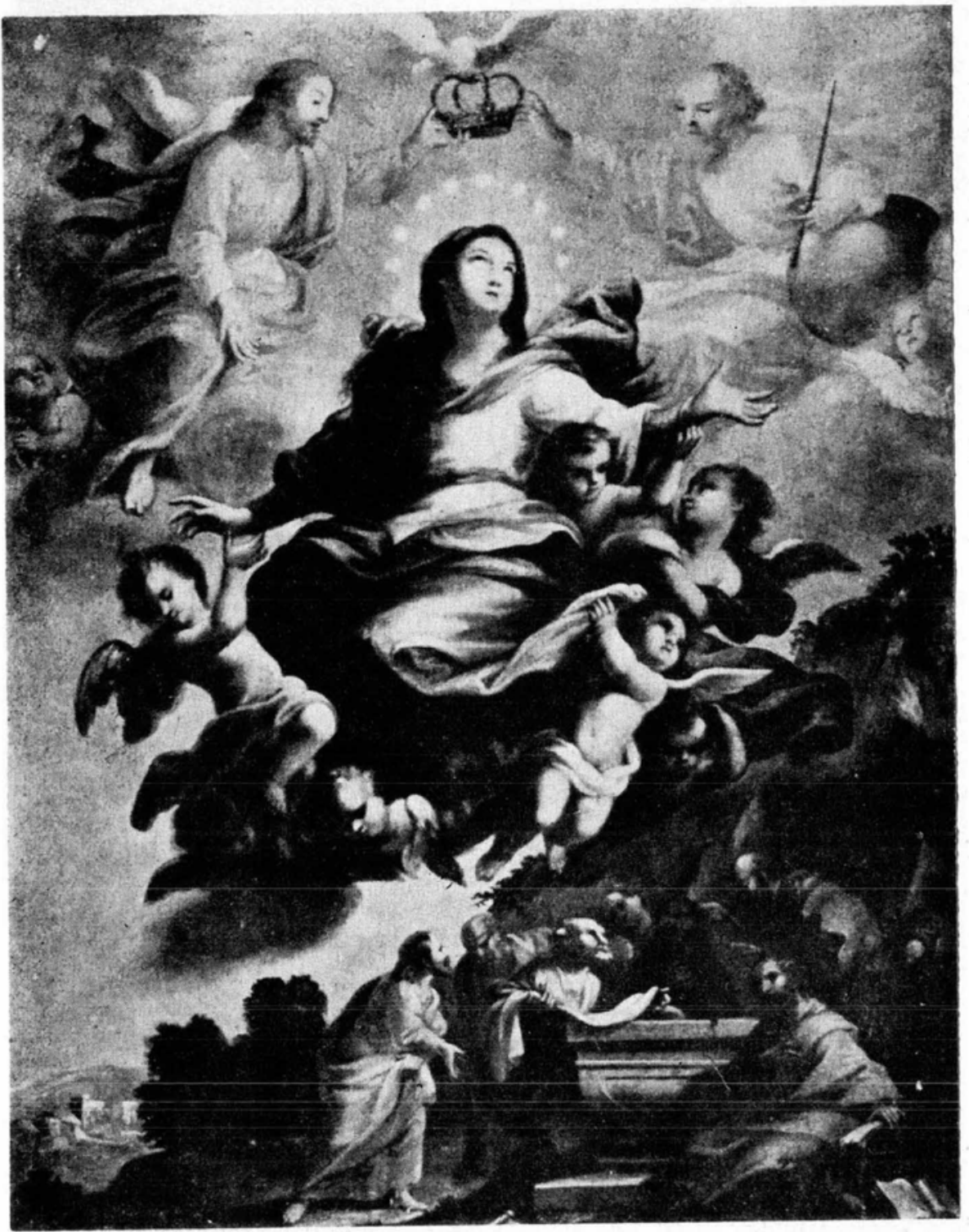

Lámina 9. José de Ibarra. Asunción de la Virgen. Siglo xviII. Éste es otro de tantos ejemplos de la pintura colonial en que se funde la representación de dos misterios marianos: el de la Asunción y el de la Coronación. 


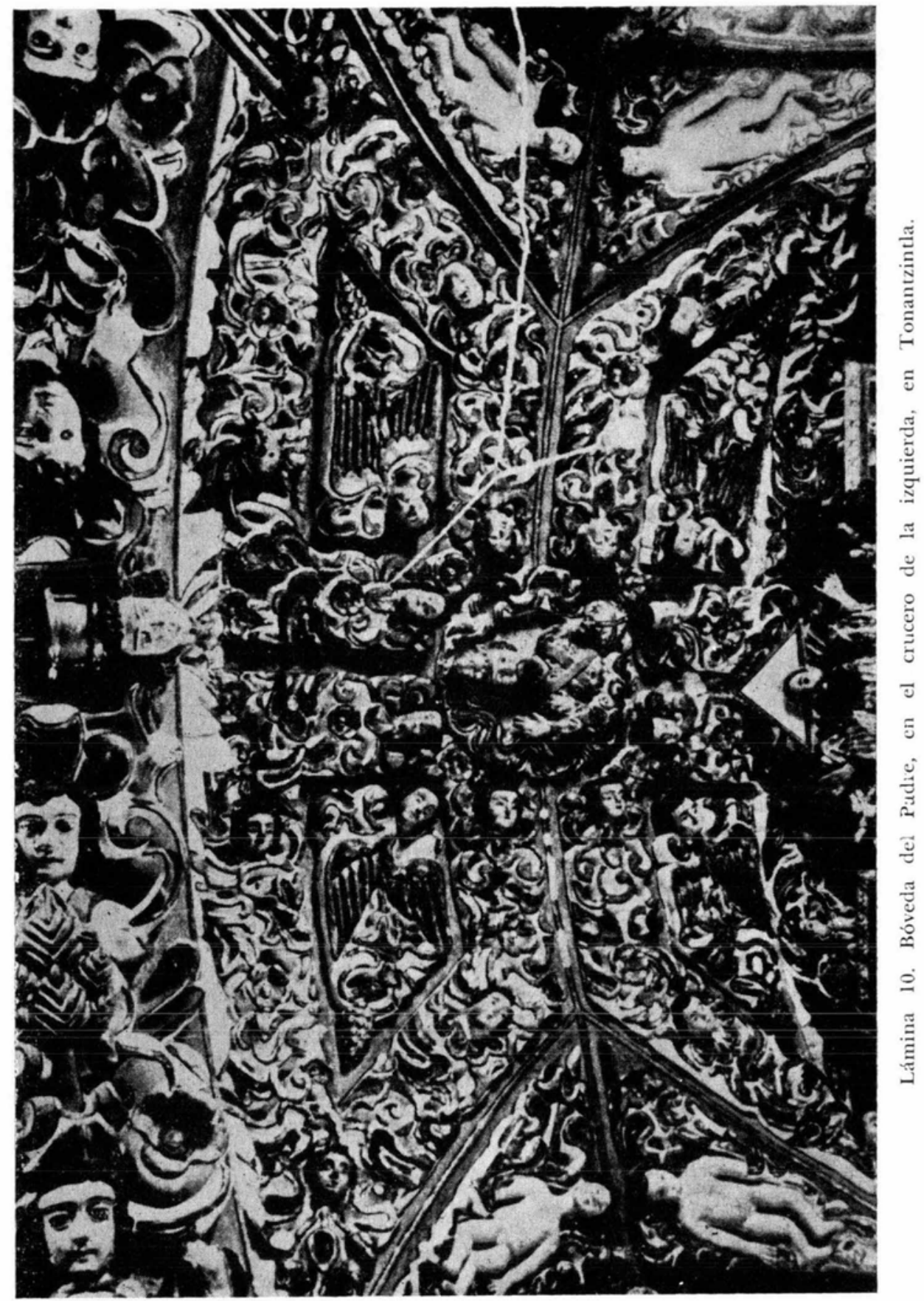




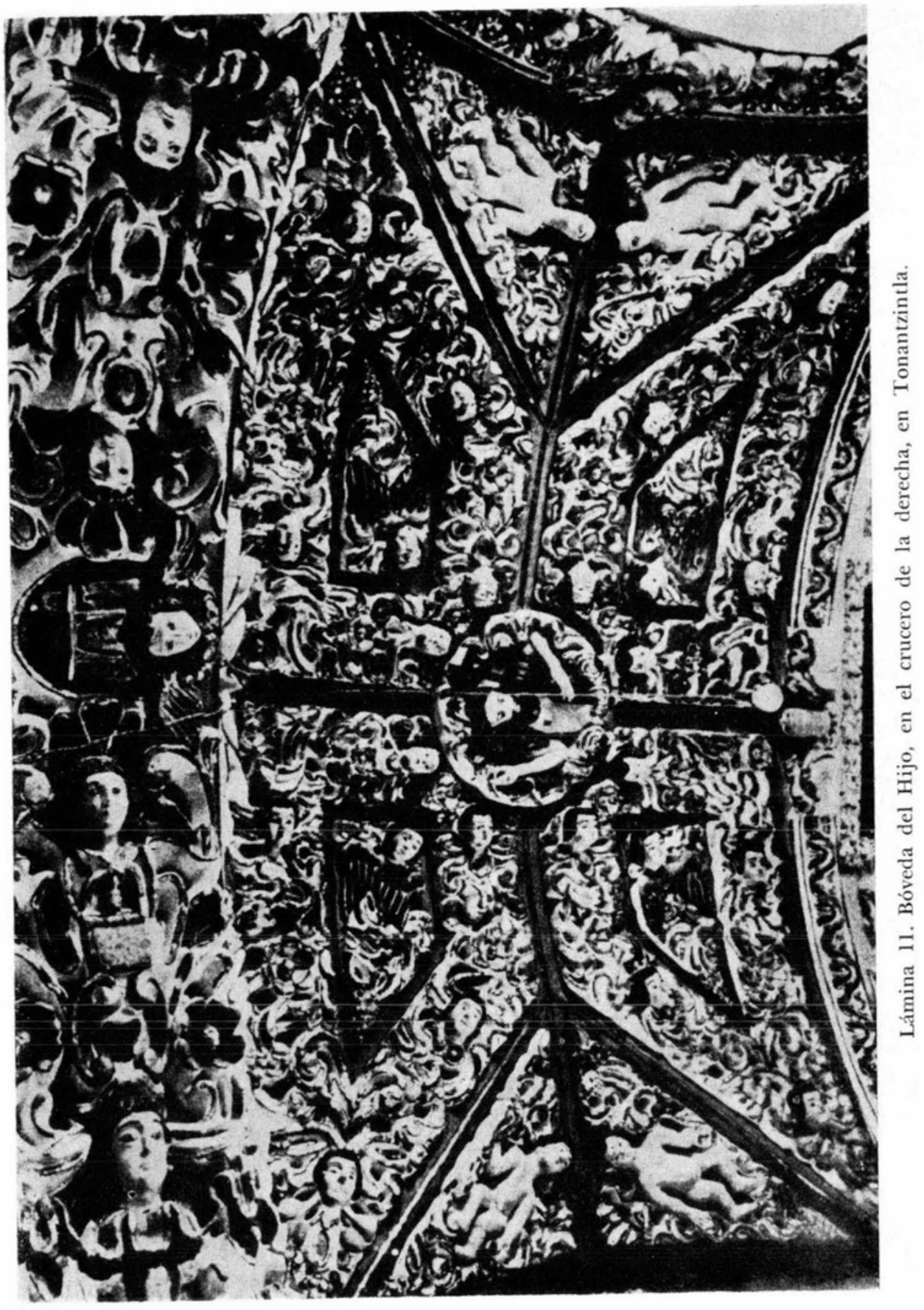




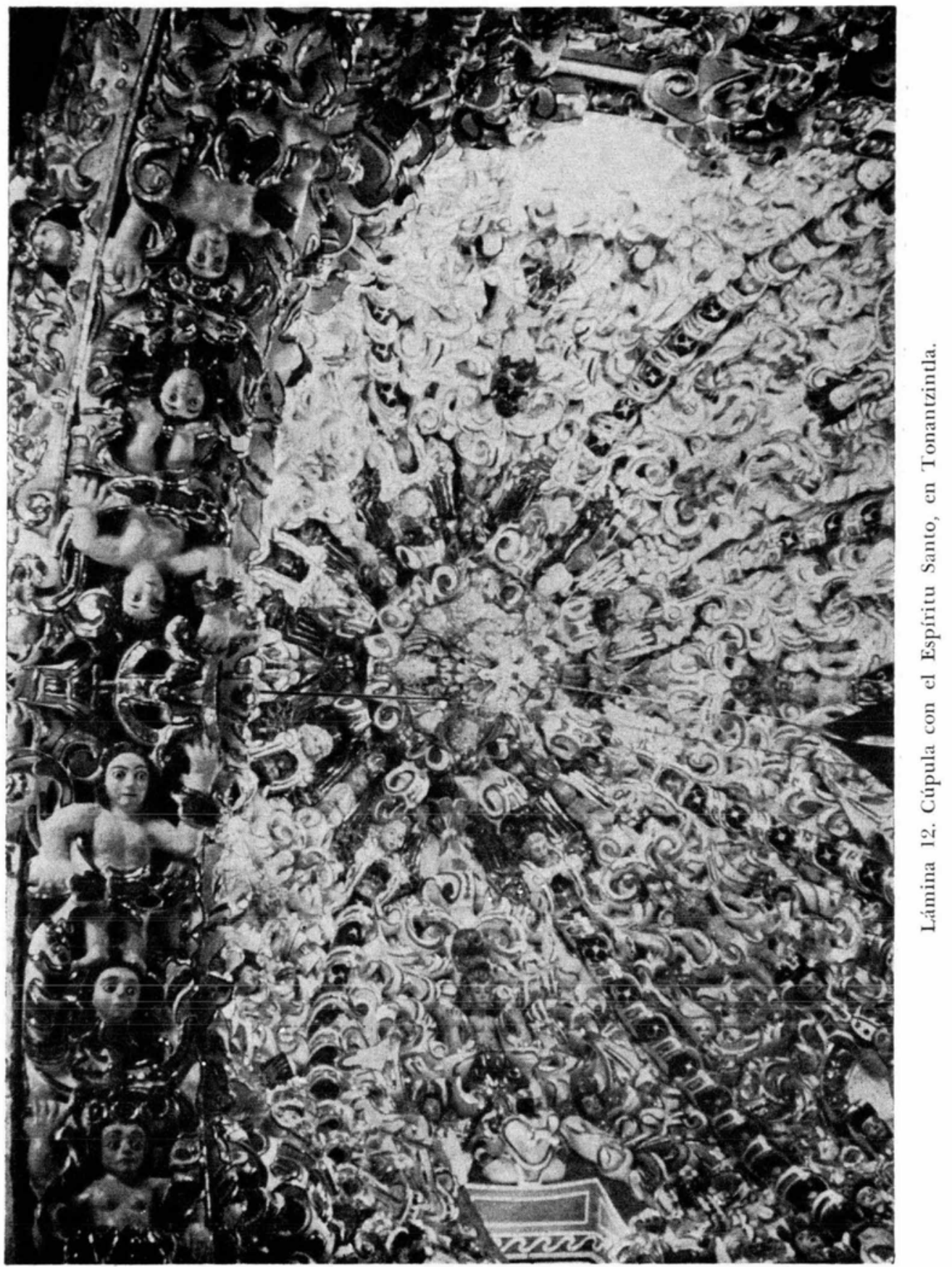




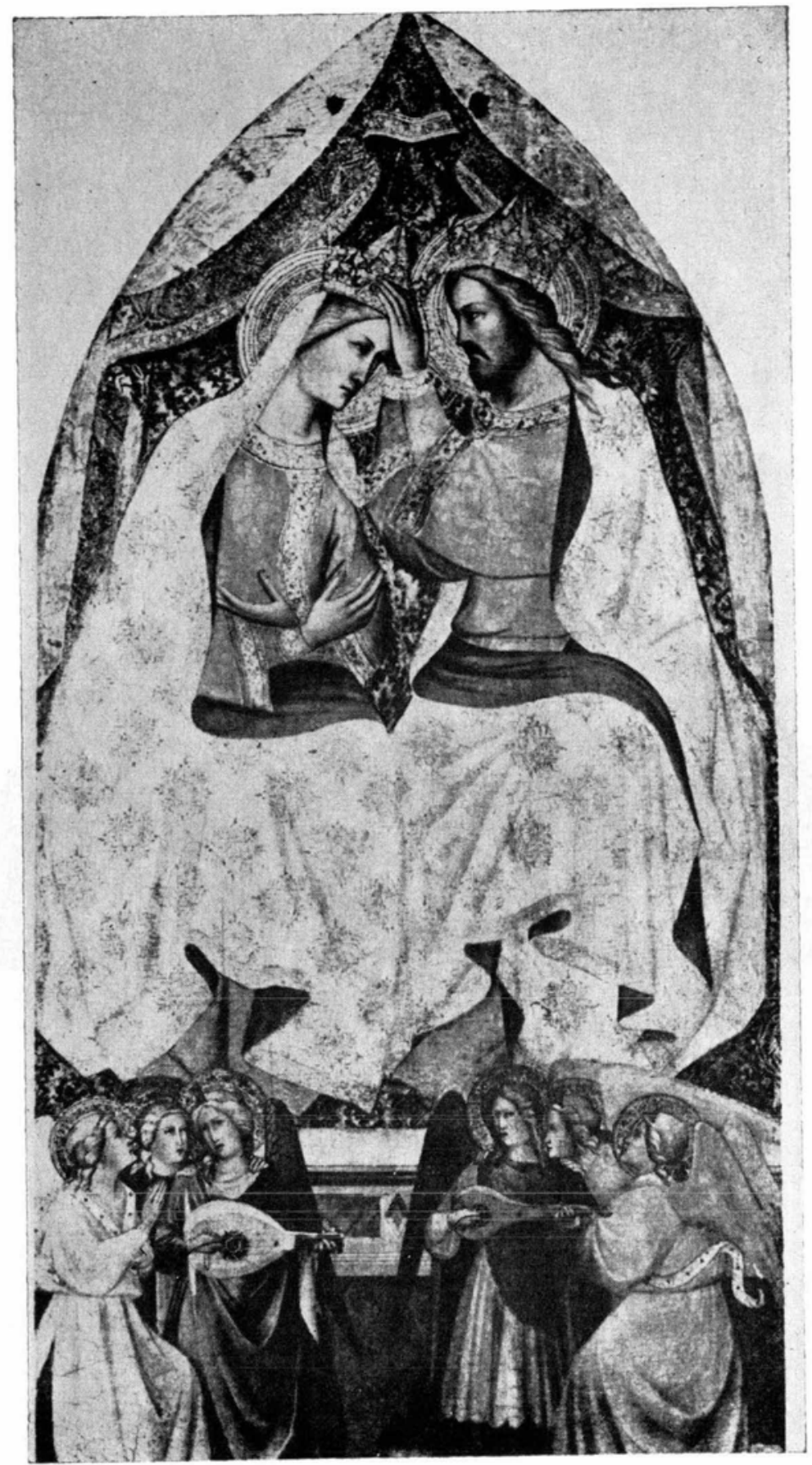

Lámina 13. Agnolo Gaddi. Coronación de la Virgen. Galería Nacional de Arte, Washington. 
DOI: http://dx.doi.org/10.22201/iie.18703062e.1978.48.1093

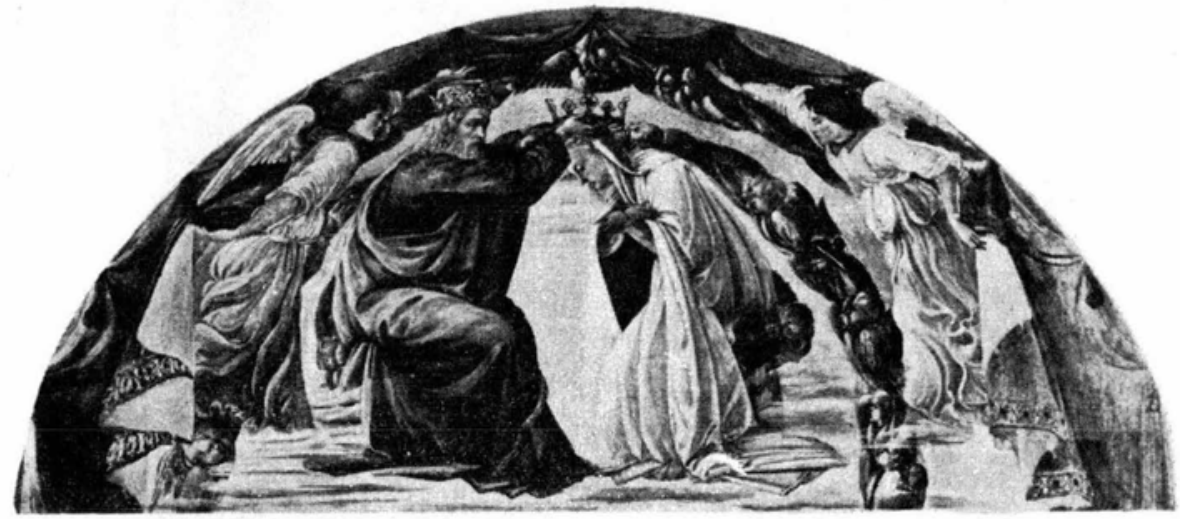

Lámina 14. Filippino Lippi. Coronación de la Virgen. Galería Nacional de Arte, Washington. 
DOI: http://dx.doi.org/10.22201/iie.18703062e.1978.48.1093

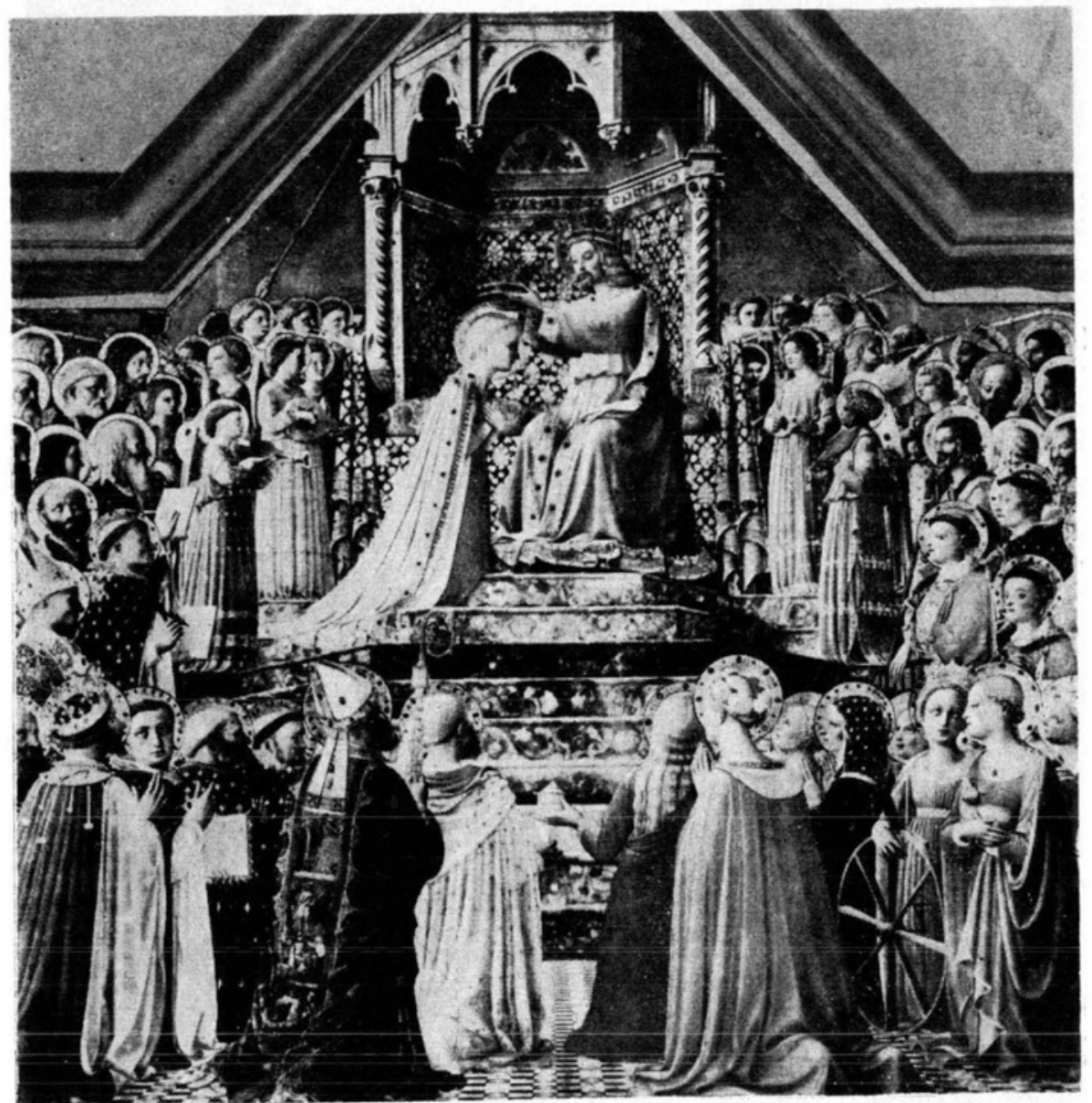

Lámina 15. Fray Angélico. Retablo de la Coronación de la Virgen. Museo del Louvre, París. 
DOI: http://dx.doi.org/10.22201/iie.18703062e.1978.48.1093

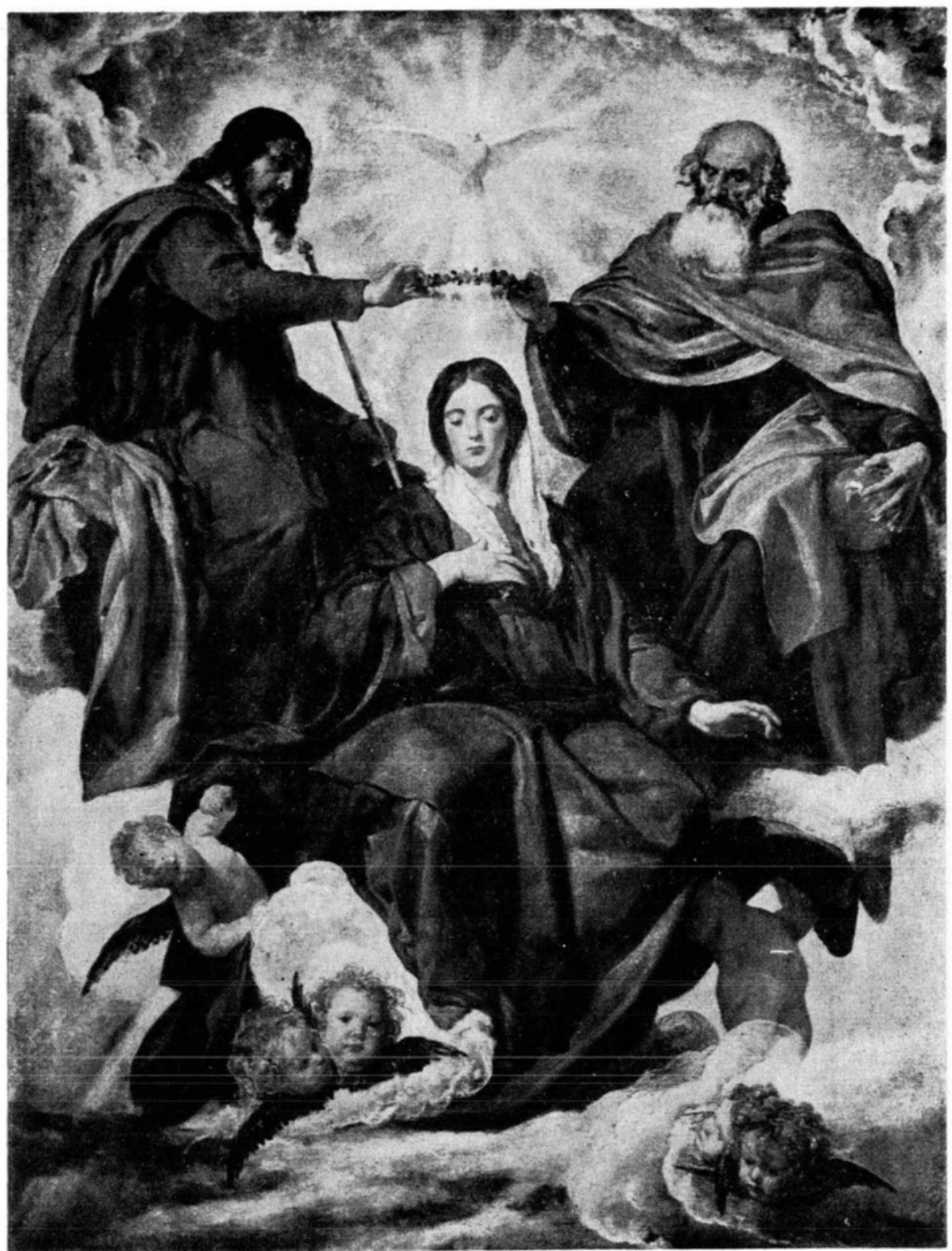

Lámina 16. Velázquez. La Coronación de la Virgen. Museo del Prado, Madrid. 


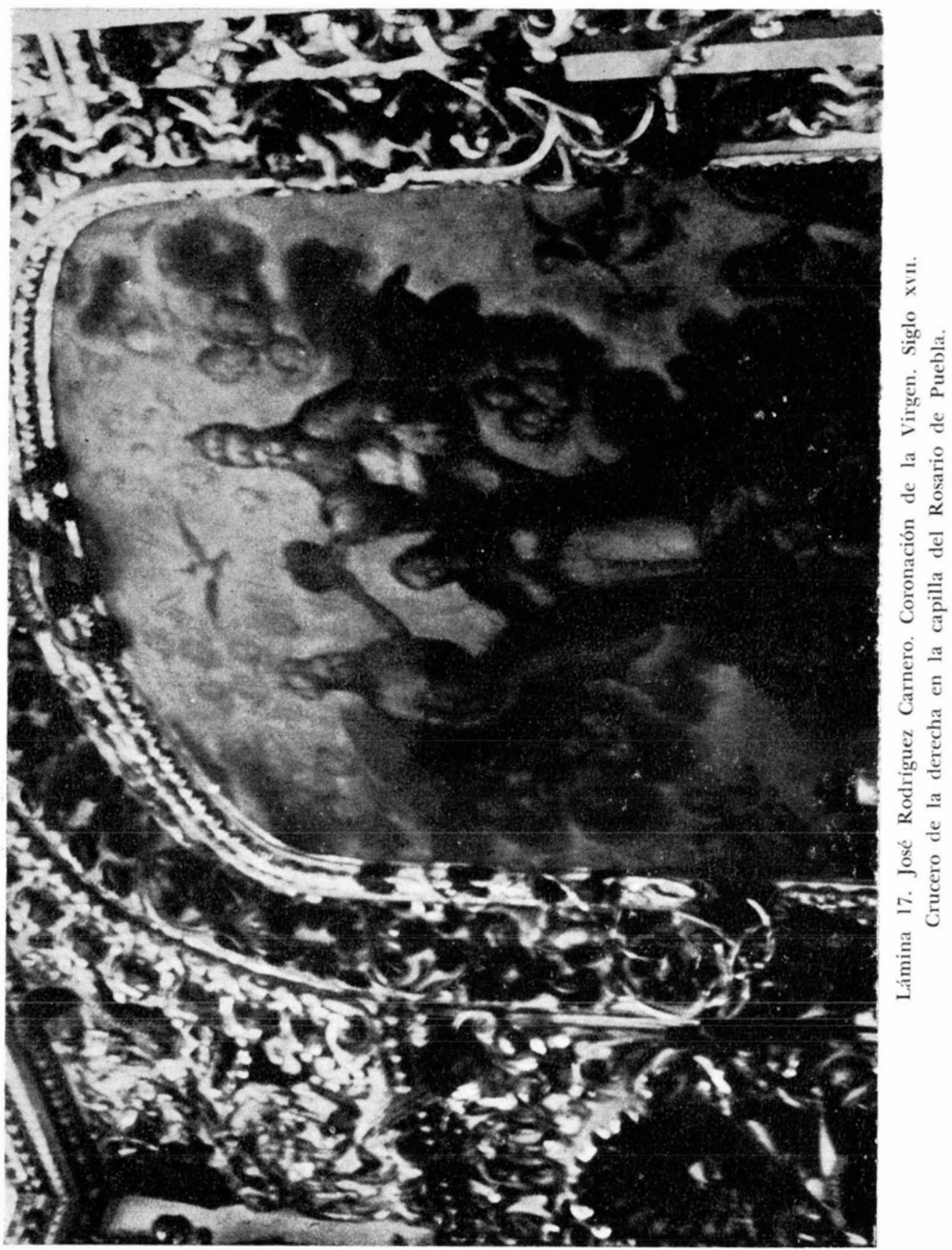


DOI: http://dx.doi.org/10.22201/iie.18703062e.1978.48.1093 
que se origina de ligar simbólicamente las imágenes; los tres ángulos superiores corresponden a la Trinidad y el inferior a Maria; el cruce de las diagonales hace el nudo de exaltación y es la base de la cúpula la que con su hervor plástico y sus incontables figurillas sintaetiza la idea (figuras 2 y 3 ).

Uniendo y cimentando tal diadema, las cuatro pechinas alojan a los evangelistas sentados en su cátedra de enseñanza, sobre ellos, que son base de verdad, los doctores de la Iglesia, de pie, en actitud de prédica, dan testimonio y son testigos de la grandeza de la Madre de Cristo.

Muchos artistas han representado la Coronación de María ante los Evangelistas y los Doctores, lo que incorpora esta cúpula a la iconografía tradicional católica, pero es probable que ninguno ha superado en riqueza imaginativa, fastuosidad plástica y fervor religioso a los anónimos creadores de Tonantzintla.

Cabe hacer notar ahora que, con apoyo en la cita bíblica de que en relación con Salomón "pusieron un trono para la madre del rey" (1, Reyes 2, 19), en la Edad Media fue común representar la Coronación de la Virgen efectuada directamente por Cristo, ante la presencia de los ángeles y de los santos, al ser recibida en los cielos. Esta fórmula tuvo especial preferencia en Italia, pues perdura en el Renacimiento y se prolonga hasta el Barroco; baste citar las varias versiones de fray Angélico y Boticelli, entre otros, como Agnolo Gaddi o Filippino Lippi (láminas 13,14 y 15$)$.

Pero, y para acercarnos a lo nuestro, en tierras hispánicas se dio primacía casi exclusiva a la representación de la Coronación de la Virgen efectuada por la Divina Trinidad en pleno, para mayor solemnidad y exaltación teológica de María. Así tenemos, entre infinidad, el caso egregio de Velázquez (lámina 16), notable además, porque la corona es de flores, ;como la de nuestro Tonantzintla!, casos de suavidad y finura poco frecuentes. En Italia recordamos a Correggio, quien al representar la Coronación de María es solo Cristo quien coloca la diadema sobre la cabeza de la Virgen; eso sí, bajo la asistencia del Espíritu Santo; pero lo distinto es que la diadema es de azucena. 8

Mas, para volver a nuestro tema, no podemos pasar por alto que en el crucero de la Capilla del Rosario de Puebla, a la derecha del espectador, un gran lienzo muestra la Coronación de la Virgen en la usual o acos.

8 Ast pinta Correggio la Coronación de la Virgen en un fresco de la iglesia de San Juan Bautista de Parma, entre 1520 y 1524, fresco hoy trasladado a la Biblioteca de la misma ciudad. 
tumbrada forma "colonial", y no debemos olvidar que este cuadro bien pudo ser la inspiración o sugerencia más inmediata para el caso de Tonantzintla ${ }^{9}$ (lámina 17).

Una reflexión importante: si bien, en Tonantzintla, la Coronación representada es la tradicional entre nosotros, donde intervienen las tres divinas personas, conforme lo hemos visto, sin embargo hay una alteración en la colocación del Padre y el Hijo, pues parecen estar al revés de lo debido iconográficamente; es decir, que el Padre está a la izquierda y el Hijo a la derecha del observador (figuras 2 y 3).

Bien lo hizo ya notar De la Maza con su natural agudeza, en su análisis de Tonantzintla: 10

De la cornisa para abajo estamos en la tierra; para arriba, es el cielo. Por ello en las bóvedas está la presencia de Dios en su forma trinitaria, si bien la jerarquía divina teológica anda un tanto trastocada, porque el Padre ocupa el crucero izquierdo; el Hijo el derecho y el Espíritu Santo el que señorea en la cúpula, en su punto culminante. $Y$ no es esto heterodoxia, porque en recta teología, cada una de las personas es Dios, si bien, de una manera convencional, el Padre es primero.

Y nosotros recordamos que la fórmula iconográfica de colocar al Padre a la derecha del espectador se origina en la idea subjetiva, que también sería mejor decir supraobjetiva, de que Cristo está "sentado a la derecha del Padre", como lo consigna el Credo.

Volviendo a Tonantzintla, debemos considerar que su alegoría plástica no es un cuadro, o sea que su forma de expresión no es únicamente apreciable como un plano bidimensional, sino que es un espacio arquitectónico interior dentro del que nos podemos mover en distintos puntos, por lo que la tridimensionalidad, óptimamente captada, será la que se proyecta desde el punto de mayor interés y hacia él, tanto en lo objetivo como en lo subjetivo, para nuestro caso constituido por el sitio más sagrado, como lo es, sin duda, el presbiterio, por la presencia en él del altar, sagrario e imagen venerada. Desde aquí, desde "el lugar de nuestra madrecita", la irregular colocación Trinitaria, yista al contrario, se invierte justamente y se hace lógica y tradicional en su forma iconográfica, tanto en "planta" como en "alzado". En planta -por así

$9 \mathrm{La}$ pintura es obra de José Rodríguez Carnero y data de fecha anterior a 1690, en que se concluyó la capilla. Véase: Francisco Pérez de Salazar, Historia de la pintura en Puebla. UNAM, 1963, pp. 71 y 72.

10 Francisco de la Maza, op. cit., "Tonantzintla, Paraiso", p. 4. 
decirlo- con vista del ábside hacia la entrada, el triángulo de relación Trinidad-María (figura 1), es el de colocación de imágenes tradicional en las Asunciones y Coronaciones Marianas; lo mismo puede decirse, y con mayor razón, en alzado, pues la representación resulta la correcta si nos colocamos desde el punto de vista de Ella, desde el lugar en que recibe el homenaje y donde permanece su imagen. Es también el lugar del rito y de la relación sacerdotal hacia los fieles.

Difícil, si no es que imposible, demostrar la intención consciente de este aserto, pero muy factible imaginarlo así en la mente de quienes elaboraron la obra ya que arrastraban, como arrastran aún, trasuntos de un animismo objetivador.

Finalmente, así, desde el lugar de la imagen -presencia sagrada-, y captado en su tridimensionalidad, el coruscante espacio que conjuga los cruceros, que son Padre e Hijo; la cúpula, el Espíritu Santo, y el ábside, María, tal espacio logra, en sentido alegórico, la exaltación plena de la Virgen en medio de la florida Gloria, con tan mágica belleza y tal magnificencia que cautiva, arrebata e incluye al contem. plador entre la muchedumbre de figurillas indigenas que, con ojos muy abiertos, están espectantes de su Tonantzin coronada en el Tlalocan.

\section{CRÉDITOS DE ILUSTRACIONES}

1 y 2. Pertenecen al Archivo Fotográlico del INAH y se publican por cortesía del mismo.

3, 5, 6, 12, 16 y 17. Proceden del Archivo Fotográfico del Instituto de Inves" tigaciones Estéticas.

4, 9, 10 y 11. Fueron tomadas del libro de Pedro Rojas, Tonantzintla. Colec. ción de Arte núm. 2. UNAM. México, 1956.

7 y 18. Se tomaron del libro de Manuel Toussaint, Pintura colonial en México. IIE, UNAM, México, 1965.

13, 14 y 15. Se obtuvieron del libro de George Ferguson, Signos y simbolos en el arte cristiano. Emecé Editores, Buenos Aires, 1956.

Las figuras 1,2 y 3 . Son dibujos del autor. 